\title{
EStudios EGerenciales
}

Journal of Management and Economics for Iberoamerica

Research article

\section{Risk information disclosure and its impact on analyst forecast accuracy}

\section{José Miguel Tirado-Beltrán*}

Professor, Department of Finance and Accounting, University Jaume I, Castellón de la Plana, Spain.

tirado@uji.es

J. David Cabedo-Semper

Professor, Department of Finance and Accounting, University Jaume I, Castellón de la Plana, Spain. cabedo@uji.es

\begin{abstract}
This paper aims to analyse the influence of risk information disclosure on the accuracy of financial analysts' earnings forecasts for the Spanish stock market. To do this, we performed a regression analysis with panel data on a sample comprised of non-financial firms listed on the Madrid Stock Exchange from 2010 to 2015. The results of the study show that risk information disclosed by firms does not help to reduce analysts' uncertainty levels nor enable them to make more accurate forecasts of future profits. Furthermore, separately testing verified and unverified risk information disclosure confirms that there is no relationship between the risk information disclosed and the perception that analysts have on companies' levels of risk.
\end{abstract}

Keywords: risk information disclosure; analyst forecast accuracy; risk.

\section{Divulgación de información sobre riesgos y su impacto en la precisión de las previsiones de los analistas}

Resumen

Este trabajo tiene como objetivo analizar la influencia de la divulgación de información de riesgo en la precisión de las previsiones de beneficios de los analistas financieros para el mercado de valores español. Para ello, se ha realizado un análisis de regresión con datos de panel para una muestra de empresas no financieras que cotizan en la Bolsa de Madrid de 2010 a 2015. Los resultados muestran que la información de riesgo no ayuda a reducir los niveles de incertidumbre de los analistas. Adicionalmente, el análisis por separado de la información de riesgos verificada y no verificada confirma que no existe relación entre la información de riesgos publicada y la percepción que los analistas tienen sobre los niveles de riesgo de las empresas.

Palabras clave: información sobre riesgos; precisión de los analistas; riesgo.

\section{Divulgação de informações de risco e seu impacto na precisão das previsões dos analistas}

\section{Resumo}

Este artigo tem como objetivo analisar a influência da divulgação de informaç̃es de risco na precisão das previsões de lucro de analistas financeiros para o mercado de ações espanhol. Para isso, foi realizada uma análise de regressão com dados em painel de uma amostra de empresas não financeiras listadas na Bolsa de Madri de 2010 a 2015. Os resultados mostram que as informações de risco não ajudam a reduzir os níveis de incerteza de analistas. Além disso, a análise separada das informações de risco verificadas e não verificadas confirma que não há relação entre as informações de risco publicadas e a percepção dos analistás sobre os níveis de risco das empresas.

Palavras-chave: informação de risco; precisão dos analistas; risco.

*Corresponding author.

JEL classification: M41; M49.

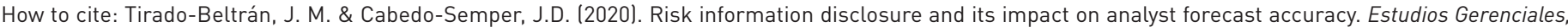
36(156), 314-324. https://doi.org/10.18046/j.estger.2020.156.3774

DOI: https://doi.org/10.18046/j.estger.2020.156.3774

Received: 8-nov-2019

Accepted: 14-may-2020

Available on line: 28 -sep-2020 


\section{Introduction}

One of the accounting regulator's main concerns is that financial statements provide useful information for users in their decision-making process. The amount of information included in financial statements has increased over the years in an attempt to meet the information needs expressed by accounting bodies and the accounting literature, with the aim of improving their usefulness for the different stakeholders (American Institute of Certified Public Accountants - AICPA, 1987; AICPA, 1994; Lev \& Zarowin, 1999; Francis \& Schipper, 1999). It has been argued that risk is one of the main areas where information is lacking (Institute of Chartered Accountants in England \& Wales (ICAEW), 1997; Solomon, Solomon, Norton, \& Joseph, 2000; Cabedo \& Tirado, 2004). Various accounting bodies have considered this lack of risk information and have consequently issued rules governing the presentation of this type of information in financial statements.

The issuance of disclosure regulations has opened up an interesting line of research into the utility of this information for different users, specifically; investors, those who prepare the information, and analysts. Two different approaches have been used to analyse utility: a direct approach, asking users about the usefulness of risk information (Abraham, Marston, \& Darby, 2012; Association of Chartered Certified Accountants (ACCA), 2014; Sarens \& D'Onza, 2017); and an indirect approach, based on observing capital market reactions through analysis of the behaviour of certain market variables, such as price, trading volume, yield and spread (Campbell, Chen, Dhaliwal, Lu, \& Steele, 2014; Kravet \& Muslu, 2013; Hope, Hu, \& Lu, 2016; Miihkinen, 2013; Nelson \& Rupar, 2015; Filzen, 2015; Jorion, 2002). These studies report contradictory results. In general terms with the direct approach, authors have called into question the utility of risk information for various reasons: information is too generic, repetitive and difficult to verify (ICAEW, 2011; ACCA, 2014). With the indirect approach, however, results generally show that the capital market appreciates risk information, although some studies report results that contradict the theoretical assumptions (Kravet \& Muslu, 2013; Campbell et al., 2014).

Most of the studies related to the risk information disclosure analyse its usefulness for a specific group of stakeholders i.e. investors. However, there are a few studies that have focused on the usefulness of this disclosure for other stakeholders such as financial analysts. Among these studies, the works of Abraham et al. (2012) and Sarens and D'Onza (2017) are relevant. These authors asked financial analysts about the usefulness of the risk information disclosed. Their results show a disparity of opinions among analysts; whilst one group perceives this information as irrelevant because it is too generic and repetitive, another group considers disclosed risk information useful. In the same vein, Kravet and Muslu (2013) have shown that the greater the disclosure of risk information, the greater the dispersion in analysts' profit forecasts around the date of publication of financial statements. Nevertheless, the accounting literature, up until now, has not tackled how risk information disclosure impacts on analysts' forecasts of future profits. This paper endeavours to address this omission through a study of Spanish firms.

The present paper uses the indirect approach to study the hitherto unexamined impact of risk information on the accuracy of financial analysts' earnings forecasts. It must be remembered that financial analysts use both public and private sources of information to evaluate firms' performance and make earnings forecasts (Healy \& Palepu, 2001; Francis \& Schipper, 1991). The data in financial statements is an important source of information (Ramnath, Rock, \& Shane, 2008). In theory, more comprehensive detail on risks should reduce uncertainty for users (including analysts) regarding future cash flow and earnings, improving the quality of their forecasts and thus having a positive impact on accuracy.

This empirical study is based on a sample of firms trading on the Spanish capital market with data for the period between 2010 and 2015. The impact of risk information on analyst forecasts was determined by running a regression analysis with panel data. The models use analysts' earnings forecast errors as the dependent variable and disclosed risk information as the independent variable. The degree of disclosed risk information was quantified using the index proposed by Cabedo and Tirado (2009). These authors built a risk disclosure index based on the content rather than on the amount of information disclosed (the technique used in most studies involves taking the number of key phrases or words as an indicator of the amount of disclosed risk information). Control variables have also been introduced which, according to the literature, affect the accuracy of analysts' earnings forecasts (size, leverage, analyst divergence, audit firm, analyst monitoring, earnings quality, profit variability and yield volatility). The results show that risk information taken as a whole is not related to the accuracy of analyst earnings forecasts.

In addition to the above analysis, this study examines the relationship between verifiable disclosed risk information and earnings forecast accuracy lanalyst earnings forecast error). Thus, based on the literature review, the structure of the present study is two-fold. Firstly, disclosed risk information was divided into three components; risk factors, management of (verifiable) risks, and quantitative information on the impact of (non verifiable) risks. The relationship of each of the above components to earnings forecast accuracy was then analysed. When risk information was taken as a whole, no statistically significant relationship was detected between any of these three components and analysts' profit forecast accuracy. Secondly, published risk information was divided into two categories; verified and unverified. Analysis of the relationship between each of these components and forecast accuracy confirms that there is no statistically significant relationship.

The rest of the paper is structured as follows: section two reviews the existing literature and proposes the hypotheses for testing. The third section presents the methodology used to test the hypotheses, describes the sample and presents the data. The results of the empirical study are shown in section four. The paper ends with a presentation of the main conclusions from the study. 


\section{Theoretical framework and hypotheses}

Scholars have paid particular attention to studying the factors that influence earnings forecast accuracy. It has been shown that firm size (Lang \& Lundholm, 1996), analyst monitoring of the firm (Lang \& Lundholm, 1996; Bozzolan, Trombetta, \& Beretta, 2009; Ding, Luo, Hao, \& Zhang, 2017), changes in earnings (Duru \& Reeb, 2002), yield volatility (Jaggi \& Jain, 1998; Duru \& Reeb, 2002), international diversification (Duru \& Reeb, 2002) and the quality of accounting information (Lang \& Lundholm, 1996; Barron, Kile, \& O'Keefe, 1999; Hope, 2003; Horton, Serafeim, \& Serafeim, 2013; Glaum, Baetge, Grothe, \& Oberdörster, 2013) are important factors with an impact on the accuracy of analyst earnings forecasts.

Analysts point to the quality of financial statements as an important factor when assessing the usefulness of this information (Healy, Hutton, \& Palepu, 1999). Thus, highquality accounting information enables analysts to make more realistic forecasts with smaller deviations between their forecasts and actual events, as Lang and Lundholm (1996) and Glaum et al. (2013) have shown. Lang and Lundholm (1996) report that an increase in information quality lthey use Financial Analysts Federation ratings for US firms as a measure of quality), increases analyst earnings forecast accuracy. Hope (2003) reaches similar conclusions for a sample of firms from 22 countries. Other works have analysed the effect of International Accounting Standards (IFRS) on earnings forecast accuracy (Glaum et al., 2013; Garrido \& Sanabria, 2014; Horton et al., 2013; Ashbaugh \& Pincus, 2001; Hodgdon, Tondkar, Harless, \& Adhikari, 2008; Tan, Wang, \& Welker, 2011; Byard, Li, \& Yu, 2011).

Although accounting researchers have focused on the impact of certain accounting information on improving analyst earnings forecasts (Vanstraelen, Zarzeski, \& Robb, 2003; 2003; Bozzolan et al., 2009; Bernardi \& Stark, 2018; Kou \& Hussain, 2007) there are no papers analysing the influence of firms' disclosure of risk information on the accuracy of analyst earnings forecasts, with the exception of recent work by Lin and Lin (2017).

Authors such as Solomon et al. (2000) and Cabedo and Tirado (2004) have emphasised the usefulness of this information for user decision making. Consequently, a series of theoretical (Jorgensen \& Kirschenheiter, 2003; Heinle \& Smith, 2015; Heinle \& Smith, 2017) and empirical works (Rajgopal, 1999; Linsmeier, Thornton, Venkatachalam, \& Welker, 2002; Jorion, 2002; Moumen, Othman, \& Hussainey, 2015; Campbell et al., 2014; Kravet \& Muslu, 2013; Miihkinen, 2013; Zreik \& Louhichi, 2017; Cabedo \& Tirado-Beltrán, 2014; Filzen, 2015; Hope et al., 2016) have studied the impact of risk information on capital markets. These studies show that risk information disclosure influences share prices (Campbell et al., 2014; Filzen, 2015; Hope et al., 2016), affects investors' perception of risk (Campbell et al., 2014; Kravet \& Muslu, 2013), helps to reduce information asymmetry (Campbell et al., 2014; Kravet \& Muslu, 2013; Miihkinen, 2013) and affects the cost of capital (Jorgensen \& Kirschenheiter, 2003; Heinle \& Smith, 2017).
The results reported in empirical works show that investors take into account the disclosure of larger amounts of risk information and adjust their expectations (Campbell et al., 2014; Filzen, 2015; Hope et al., 2016). This implies that risk information disclosure has an impact on investors' estimation of future cash flows and profits when evaluating firms' shares. In this vein, if analyst earnings forecasts are taken as a proxy for these expectations as Fried and Givoly (1982) point out, it seems reasonable to think that if risk information has significant informative content, it will help to reduce uncertainty over cash flows or future earnings and will therefore redound to more accurate forecasts. Lin and Lin (2017) study how the requirements of Financial Reporting Release No. 48 (FRR No. 48) regarding the format firms can choose to disclose information on their exposure to market risk (tabular, sensitivity analysis and value at risk $\mathrm{VaR}$ ) affect the accuracy of analyst profit forecasts. Lin and Lin (2017) show that prediction errors are smaller in firms that use $\mathrm{VaR}$ and the tabular format than in firms that use sensitivity analysis. These results show that information on exposure to market risks has an informative content for analysts because it enables them to make more accurate profit forecasts. In contrast, the study by Abraham et al. (2012) analysing financial analysts' perception of the risk information divulged by firms in the UK, shows that one group of the analysts interviewed consider that risk information is useful, whereas according to another group the information is irrelevant due to it being too general and repetitive. Sarens and D'Onza (2017) reached similar conclusions in their study of analyst perceptions of information disclosed on risk, its management and internal control in Belgium and Italy.

One may consider risk information as forward-looking information. Aljifri and Hussainey (2007, p.883) note that "forward-looking disclosure also involves non-financial information such as risks and uncertainties that could significantly affect actual results and cause them to differ from projected results". In this vein, several studies have discussed the usefulness of forward-looking information for financial analysts: Bozzolan et al., (2009), Beretta and Bozzolan, (2008) and Vanstraelen et al., (2003) show that the greater the amount of forward-looking information provided by firms, the higher the accuracy in analysts' profit forecasts. In view of the above arguments, the following hypothesis was formulated:

- Hypothesis 1: firm risk information disclosure is related to the accuracy of analyst earnings forecasts.

In addition, Crawford and Sobel (1982) point out that, on balance, information that cannot be verified has no informative content and therefore users do not value it. In this regard, Dobler (2008) notes that risk information includes aspects which are verifiable lon matters such as risk factors and their management) and therefore credible. That is, analysts can take them into account (Hutton, Miller, \& Skinner, 2003; Bozzolan et al., 2009). Other elements, like those concerning disclosure of the impact of the risk, are not verifiable and so, a priori, they may or may not be credible. 
The informative content of this type of data depends on the degree of credibility ( $N g$, Tuna, \& Verdi, 2013; Mercer, 2004; Rogers \& Stocken, 2005). Therefore:

- Hypothesis 2: risk information disclosed by firms that is verified or verifiable is related to the accuracy of analysts' earnings forecasts.

\section{Methodology}

\subsection{Models}

The hypotheses presented in the above section were tested with the following models.

$$
\begin{gathered}
F E_{i, t}=\beta_{o}+\beta_{1} R D I_{i, t}+\sum_{j=2}^{n} \beta_{j} C_{i, j, t}+\varepsilon_{i, t} \\
F E_{i, t}=\beta_{o}+\beta_{1} D V R D I_{i, t}+\beta_{2} I V R D I_{i, t}+\beta_{3} M V R D I_{i, t}+\sum_{j=4}^{n} \beta_{j} C_{i, j, t}+\varepsilon_{i, t} \\
F E_{i, t}=\beta_{o}+\beta_{1} V R D I_{i, t}+\beta_{2} N V R D I_{i, t}+\sum_{j=3}^{n} \beta_{j} C_{i, j, t}+\varepsilon_{i, t}
\end{gathered}
$$

where $F E_{i, t}$ is analyst earnings forecast error per share for firm $i$ and year $t$; $R D l i, t$ is the risk disclosure index of firm $i$ in year $t$; DVRDlit is the disclosure index that collects information on the different risk factors for firm $i$ in year $t$; IVRDlit is the index that collects information on the impact of various risks for firm $i$ in year $t$; MVRDlit is the index that collects information on the management of the different risks for firm $i$ in year $t$; $V R D l i, t$ is the verified risk disclosure index for firm $i$ in year $t$; NVRDli, is the non-verified risk disclosure index for firm $i$ in year $t ; C, i j$, , are the control variables, $\beta$ represents the parameters of the model to be estimated and $\varepsilon$ are the residuals.

The first model (1) tests hypothesis 1, which studies the relationship between risk information disclosure in financial statements and the degree of analyst forecast accuracy. Models (2) and (3) test hypothesis 2, which analyses the relationship between verifiable and verified risk information with analyst earnings forecast accuracy per share.

We ran a regression analysis with panel data for the models' estimation. As a first step, we computed Haussman's test to determine whether a fixed effects model or a random effects model was best suited for the data we were working with. Then, in the case of the latter, we estimated the parameters through the Generalized Method of Moments (GMM). Otherwise, when a fixed effects model was more appropriate, we estimated the parameters through the "within estimator" or "within transformation". This returned a vector that contained the values in deviation from the individual means. When the required hypotheses were fulfilled, we were able to estimate the model by using ordinary least squares by using these transformed variables.

\subsection{Dependent variable}

The present study uses earnings forecast error per share (FE) as the dependent variable to be estimated in the three models. Following Lang and Lundholm (1996), we measured earnings forecast error per share (FE) as the negative absolute value of the difference between profits per share for firm $i$ in year $t(E P S i, t)$ and the median of analyst profit forecasts per share for firm $i$ in year $t(F E P S i, t)$, all divided by the price of a share in firm $i$ at the start of year $t-1(P, t,-1)(4)$ :

$$
F E_{i, t}=-\frac{\left|E P S_{i, t}-F E P S_{i, t}\right|}{P_{i, t-1}}
$$

This magnitude is a measure of analyst forecast accuracy. Firms with higher $F E$ values will have a better forecast. Values closer to zero imply fewer forecast errors.

\subsection{Independent variables}

The proposed models incorporate information on firm risk disclosure as independent variables.

\subsubsection{Disclosure of Risk information (RDI)}

The degree of risk information disclosure (RDI) was measured using the index from Cabedo and Tirado (2009). These authors propose an index based on informative content rather than on the amount of disclosed key phrases and/or words, as an indicator of the degree of risk information disclosure. They argue that by measuring the degree using (for example) the number of phrases, the assumption is that a firm that discloses two phrases regarding a certain risk is providing twice the information compared to a firm that only uses one phrase for the same risk. In fact, the two firms may be informing on the same content, although one expresses the information with a "longer narrative". Based on that argument, the authors propose an alternative way of measuring the amount of published risk information based on disclosure indexes constructed from a series of stages or levels ${ }^{1}$.

The risk disclosure index proposed by Cabedo and Tirado (2009) is built from the following equation (5):

$$
R D l_{i}=F R D l_{i}+N F R D l_{i}
$$

Where $R D l_{i}$ is the risk information disclosure index for firm $i$; $F R D l i$ is the financial risk information disclosure index for firm $i$; and $N F R D l_{i}$ is the non-financial risk information disclosure index for firm $i$.

The financial $(F R D /)$ and non-financial risk disclosure indexes (NFRDI) are calculated according to equations (6) and (7) respectively:

$$
F R D I_{i}=\sum_{j=1}^{m} \sum_{i f=1}^{K f f} E_{i, j}^{\prime f}
$$

\footnotetext{
${ }^{1}$ On the various alternatives for measuring information published by firms, see Beattie Mclnnes, and Fearnley (2004).
} 
where $r f$ is the type of financial risk; $E_{i, j}^{r f}$ is the value of stage $j$ of financial risk rf for firm $i ; E_{i, j}^{r f}$ will take a value of 1 if firm $i$ is at that stage and 0 if it is not; $m$ is the number of stages.

$$
N F R D I_{i}=\sum_{j=1}^{m} \sum_{r N f=1}^{K r N f} \sum_{h=1}^{n} f_{i, h} E_{i, j}^{r N f}
$$

where $r N f$ is the type of non financial risk; $E_{i, j}^{r N f}$ is the value of stage $j$ of the non-financial risk $r N f$ for firm $i ; E_{i, j}^{r N f}$ will take a value of 1 if firm $i$ is at this stage and zero if it is not; and $f_{i, h}$ represents the risk factors in the case where a category of non-financial risk presents information on more than one risk factor; fi,h will take value 1 for each $n$ factor in each nonfinancial risk.

The following five stages have been used to build the above indices:

- Stage 1: the firm only mentions the risks it is exposed to.

- Stage 2: the firm describes the risk and how it is affected.

- Stage 3: the firm informs on quantitative measurement of the impact of the risk

- Stage 4: the firm informs on risk management.

- Stage 5: the firm informs on the type of instruments used to mitigate the risk.

Risk information has been classified with the business risk model proposed by Arthur Andersen and used by ICAEW (1997) to provide a framework for business risk disclosure. Authors such as Linsely and Shrives (2006) and Kajuter (2001) have used this model to analyse the degree of risk disclosure in the UK and Germany respectively. Table A1 in the appendix presents the classification used for the types of risks.

The components of this Risk Disclosure Index (RDli) have been used to calculate the indices for the verifiable and nonverifiable components of risk information and the verified and unverified components in that information.

In the case of verified and unverified components, for model (3) a verified risk disclosure index (VRDI) and a nonverified risk disclosure index (NVRDI) was calculated as follows:

VRDI should be calculated by taking risk information from annual accounts verified by an audit company. In this case, listed Spanish firms must present their consolidated financial statements in accordance with International Accounting Standards (IAS). In this regard, the International Financial Reporting Standard (IFRS No. 7) regulates the disclosure of information in financial statements on financial instruments, the associated risks and policies for managing those risks. Thus, risk information that undergoes a verification process stems from financial risks. Therefore, verified risk information (VRDI) has been measured through the abovementioned financial risk disclosure index (FRDI). VRDI has been assimilated within FRDI.

As regards unverified information, in the case of Spain, Article 262 of the Capital Companies Law (Ley Sociedades de Capital, 2010) establishes the obligation to disclose, in the management report, information on the main risks and uncertainties facing the firm. In addition, the regulations indicate that the management report must include information on the objectives and policies for financial risk management, including the policy used to cover those risks and inform on exposure to price risk, credit risk, liquidity risk and cash flow risk. Thus, the management report does not neglect the need to inform on non-financial risks but managers are left free to inform on the aspects they consider noteworthy. Although the information on financial instrument risks is subject to a verification process (external audit) on the non-financial risk information disclosed in the management report, there is no obligation to verify that information as there is for the annual accounts. The regulations establish that the content of the management report must be in keeping with the annual accounts, but there is no requirement to provide verification. For that reason, the information on non-financial risks has been considered non-verified risk information. Thus the nonfinancial risk disclosure index (NFRDI) has been taken as a measure of non-verified risk disclosure information). NVRDI and NFRDI have been assimilated.

Finally for model (2) verifiable and non-verifiable information were distinguished by constructing an index for each of the aspects indicated by Dobler (2008):

The index that measures verifiable aspects concerning information on the main risk factors (DVRDli) was calculated according to equation (8):

$$
D V R D I_{i}=\sum_{j=1}^{2} \sum_{r f=1}^{K r f} E_{i, j}^{r f}+\sum_{j=1}^{2} \sum_{r N f=1}^{K r N f} E_{i, j}^{r N f}
$$

where the variables have the meaning defined in expressions (6) and (7). Specifically, subindex $j$ refers to the stage. That is, $E_{i, j}^{r f}$ and $E_{i, j}^{r N f}$ will take a value of 1 if firm $i$ is at stage 1 or 2 , and zero if it is not.

For the aspect regarding management policies and hedging instruments (verifiable) the index MVRDli is built in accordance with equation (9).

$$
M V R D I_{i}=\sum_{j=4}^{5} \sum_{r f=1}^{K r f} E_{i, j}^{r f}+\sum_{j=4}^{5} \sum_{r N f=1}^{K r N f} E_{i, j}^{r N f}
$$

The significance of the variables is the same as before. Therefore, $E_{i, j}^{r f}$ and $E_{i, j}^{r N f}$ will take a value of 1 if firm $i$ is at stage 4 or 5 and zero if it is not.

And for the third aspect, measurement of the impact of (non-verifiable) risk, index IVRDli was built according to equation (10).

$$
I V R D I_{i}=\sum_{r f=1}^{K r f} E_{i, 3}^{r f}+\sum_{r N f=1}^{K r N f} E_{i, 3}^{r N f}
$$

$E_{i, j}^{r f}$ and $E_{i, j}^{r N f}$ they will take a value of 1 if firm $\mathrm{i}$ is at stage 3 and zero if it is not.

As a first step to devise these indices, a coding of the risk information disclosed by firms in their notes to the financial 
statements and their management reports has been conducted. The information has been coded according to the kind of risk (see annex) and the aforementioned stage.

Two technicians coded the information for three months. Then, $10 \%$ of the coded documents (notes to the financial statements and management reports of 35 companies) were randomly chosen. This sample was analysed by a researcher to assess the consistency between the coding performed by both technicians. Cohen's Kappa coefficient was calculated with this aim. The value of this coefficient, 0.96 , fits the very good consistency' tranche proposed by Landis and Koch (1977).

\subsubsection{Control variables}

The control variables in the models are based on prior research. The following control variables have been used to control for the impact of factors other than that of risk information:

Size: Measured by the logarithm of market capitalisation for company $i$ in year $t$. Previous studies have found a negative relationship between size and forecast error, which indicates that analysts achieve greater accuracy with major companies (Lang \& Lundholm, 1996; Brown, 1997; Garrido \& Sanabria, 2014; Glaum et al., 2013).

Analysts: Measured by the logarithm of the number of analysts monitoring the firm. Studies by Duru and Reeb (2002), Basu, Hwang, and Jan (1998) show a negative relationship between the number of analysts who are monitoring the firm and analysts' earnings forecast errors. These results are consistent with the theory that firms more closely monitored by analysts require greater analysis, which then generates better forecasts.

Yield volatility (DesvROA): Kross, Ro, and Schroeder (1990). Kross et al. (1990) and Jaggi and Jain (1998) conclude that profit volatility is associated with greater analyst profit forecast errors. Volatility has been measured using standard deviation of the yield on assets in the last 5 years.

Earnings quality: Adjustments for abnormal accruals taken in absolute values are used to measure earnings quality. The higher the absolute value of adjustments for accrual, the lower the quality of the earnings. We have used the Jones (1991) model to measure accounting discretionality. The residuals of the regression of Jones' (1991) expectations model, as suggested by DeFond and Jiambalvo (1994) are expressed as follows (11):

$$
\mid \text { Accruals }_{i, t} \mid=\beta_{o}+\beta_{1} \Delta \text { Sales }_{i, t}+\beta_{2} \text { Ppe }_{i, t}+\varepsilon_{i, t}
$$

where Accrualsit, represents adjustments for total expected accruals for year $t$, calculated directly as the difference between the operating result and the operating cash flows divided by total assets in $t-1 ; \Delta$ Salesi,t is the annual variation in net turnover divided by total assets in $t-1$ and Ppei,t is the amount of tangible fixed assets divided by total assets in $t-1$.

This is to say that the expected amount of accrual adjustments depends both on change in incomes and levels of tangible fixed assets. The residual of the model (Quality) represents an abnormal component of accruals which is used as a proxy for accounting discretionality. The larger this component, the lower the quality of the earnings. A positive relationship is expected between the degree of accrual adjustment and analyst forecast errors, according to studies by Ahmed, Nainar and Zhou (2005) and Wu and Wilson (2016).

Leverage (Lev): Measured as the ratio of total liabilities to total assets. Glaum et al. (2013), Chang, Hooi, and Wee (2014) and Bozzolan et al. (2009) postulate a negative relationship between the degree of firm leverage and the accuracy of analyst earnings forecasts. That is, the greater the degree of leverage in firms the greater the forecast error.

Big4: Behn, Choi, and Kang (2008) show a positive relationship between the fact that the company is audited by one of the major audit companies (Big4) and analyst earnings forecast accuracy. Audit quality is introduced in the model as a dummy variable, Big4, which takes the value 1 if the firm is audited by an audit company from one the four major audit companies, and zero otherwise.

Earnings variability (VarEPS): Duru and Reeb (2002) and Hope (2003) show that analyst forecast accuracy is related to the magnitude of changes in earnings. Wide variations in earnings hinder analyst profit forecasts. For the Spanish case, Larran and Rees (1999) conclude that sectors with the greatest changes in earnings have the greatest forecast errors. Changes in earnings have been measured as the variation in the annual earnings growth divided by the price of shares at the start of the period.

Loss: Prior research indicates that analysts have difficulties making earnings forecasts when firms make a loss. Abarbanell and Lehavy (2002) show that forecast errors are greater in firms with losses. Hope (2003) also concludes that there is a negative, but not significant relationship. Therefore, it is expected there will be a negative relationship between the variable that represents loss and analyst forecast error. Loss is included in the model as a dichotomous variable that takes the value 1 when the firm made a loss in the previous year and zero otherwise.

Analyst deviation (DivAnalysts): Bamber, Barron, and Stober (1997) indicate that analyst dispersion is a proxy for uncertainty. A higher degree of uncertainty suggests greater difficulty with profit forecasting and therefore a higher likelihood of error (Hutton, Lee, \& Shu, 2012). In this regard, Lang and Lundholm (1996) show a negative relationship with analyst forecast accuracy. In this study, the variable has been measured as the standard deviation of analyst forecasts of profit per share in the $\mathrm{I} / \mathrm{B} / \mathrm{E} / \mathrm{S}$ forecast database.

\subsection{Sample}

As shown, the objective of the present study is to analyse the influence of risk information disclosed by firms in their financial statements on the accuracy of financial analysts' earnings forecasts. To test the hypotheses derived from this objective, we used a sample comprised of non-financial firms listed on the Madrid Stock Exchange (Spain) from 2010 to 2015, for which analyst profit forecasts per share are available 
on the Thomson One database. The initial sample included 468 observations. However, 117 observations with no available data on some control variables were removed. Therefore, the final sample contained 351 observations. Table 1 shows a breakdown of the number of firms in the sample per year.

The risk information was obtained from consolidated financial statements (annual and management reports) published on the website of Spain's National Securities Exchange Commission (CNMV). Analyst earnings forecasts were obtained from I/B/E/S (Institutional Brokers Estimation System) and earnings per share and control variables from Worldscope Database.

\section{Empirical results}

\subsection{Descriptive statistic}

Table 2 shows the main descriptive statistics for the set of variables used in the analysis. As the table shows, the mean of the risk disclosure index $(R D /)$ is 24.46, and the mean of the verified risk information index (VRD/) is 17.24, whereas the mean of the risk index that collects non-verified information (NVRDI) is only 7.22. These data show that firms offer greater levels of verified information on risks than nonverified information, as was expected given that verified risk information is compulsory, whereas non-verified risk information is voluntary. The mean of analyst forecast errors $(F E)$ in absolute values is $13 \%$ of the share price. However, it should be noted that $75 \%$ of the observations show forecast errors below $8 \%$ with a median of $2 \%$.

Table 1. Sample companies per year

\begin{tabular}{lccccccc}
\hline & 2015 & 2014 & 2013 & 2012 & 2011 & 2010 & Total \\
\hline Initial sample & 75 & 75 & 75 & 81 & 81 & 81 & 468 \\
Eliminated & & & & & & & 117 \\
Total & & & & & & & 351 \\
\hline
\end{tabular}

Source: own elaboration.

Table 2. Descriptive statistics

\begin{tabular}{lcccccc}
\hline & Min. & Max. & Mean & \multicolumn{3}{c}{ Percentiles } \\
\cline { 5 - 7 } & & & & 25 & 50 & 75 \\
\hline FE & -3.3 & 0 & -0.13 & -0.08 & -0.02 & -0.01 \\
RDI & 9 & 80 & 24.46 & 17 & 21 & 29 \\
IVRDI & 0 & 6 & 1.71 & 1 & 2 & 2 \\
DVRDI & 5 & 69 & 15.3 & 10 & 12 & 18 \\
MVRDI & 0 & 21 & 7.80 & 5 & 7 & 10 \\
VRDI & 6 & 32 & 17.24 & 15 & 17 & 20 \\
NVRDI & 0 & 48 & 7.22 & 0 & 4 & 11 \\
Size & 9.62 & 18.21 & 13.86 & 12.44 & 14.09 & 15.02 \\
Analysts & 0.69 & 3.76 & 2.45 & 1.95 & 2.56 & 3.09 \\
Quality & 0 & 0.43 & 0.04 & 0.02 & 0.03 & 0.05 \\
Lev & 0 & 107.59 & 34.3 & 19.14 & 32.99 & 47.48 \\
VarEPS & 0 & 8.59 & 0.2 & 0.01 & 0.03 & 0.12 \\
DesvROA & 0.09 & 17.44 & 3.06 & 1.18 & 2.13 & 3.84 \\
DivAnalysts & 0 & 2.84 & 0.06 & 0.01 & 0.01 & 0.02 \\
\hline
\end{tabular}

Source: own elaboration.
With respect to verifiable information, the mean of the disclosure index that collects information on the different risk factors (DVRDI) and of the index on management information for the various risks (MVRDI) are 15.3 and 7.8 respectively. Companies offer on average a greater level of information on the risk factors they are exposed to than on the management policies and hedging tools the company uses to mitigate them. As regards non-verifiable information, the mean of the disclosure index on the impact of the different risks of the company is 1.7 . Note that only $25 \%$ of the observations present information with a greater impact on both types of risks.

Table 3 presents Pearson correlations between the independent variables used in the regressions. The correlations between the independent variables are low for the three models. Therefore, there is no sign of multicollinearity problems since, except for the relationship between 'Analysts' and 'Size', none of the correlation coefficients for independent variables of the three estimated models is higher than 0.8 (Gujarati, 2003). We have included 'Analysts' and 'Size' within the models because both are key variables to consider when analysing the impact of information disclosure on the accuracy of financial analysts' earnings forecasts (Duru \& Reeb, 2002 and Bozzolan et al., 2009).

\subsection{The effect of risk information disclosure on the accuracy of analyst earnings forecasts.}

Table 4 shows the results of estimating the model for equation (1) used to test the first hypothesis posited in the study. When estimating the model through OLS, we detected no residual autocorrelation (we performed the DurbinWatson test). Nevertheless, the results of White's test indicate that there is heteroskedasticity in the residuals of the models. Therefore, we have estimated the model using the Generalised Least Squares technique. The number of observations used, as indicated, is 351 with a multiple $\mathrm{R}^{2}$ of 0.7148 . The model tests the relationship between earnings forecast error $(F E)$ with the degree of risk information disclosure, measured using the risk disclosure index $(R D /)$. The coefficient for the $\mathrm{RDI}$ variable is negative but not significant. This indicates that the risk information firms disclose is not related to the degree of analyst earnings forecast accuracy. These findings are in line with studies by Abraham et al. (2012) and Sarens and D'Onza (2017). The sign of the coefficients for the control variables is consistent with previous studies. The coefficients of the variables Lev, Quality, VarEPS, Loss and DivAnalysts are statistically significant and negative. This finding shows that a greater level of leverage (Lev), a higher level of accrual adjustments (Quality) -which means lower quality in the results-, greater variation in profits (VarEPS), the existence of negative results (Loss) and a greater divergence between analyst expectations (DivAnalysts) are related to lower forecast accuracy. In addition, Size is the only significant variable positively related to forecast accuracy. 
Table 3. Pearson correlation matrix

\begin{tabular}{|c|c|c|c|c|c|c|c|c|c|c|c|c|c|}
\hline Variables & $R D I$ & Lev & Size & Analysts & Quality & VarEPS & DesvROA & DivAnalysts & IVRDI & DVRDI & MVRDI & VRDI & NVRDI \\
\hline RDI & 1 & & & & & & & & & & & & \\
\hline Lev & 0.069 & 1 & & & & & & & & & & & \\
\hline Size & $0.275^{* * *}$ & $-0.143^{* * *}$ & 1 & & & & & & & & & & \\
\hline Analysts & $0.159 * * *$ & $-0.099 *$ & $0.828^{* * *}$ & 1 & & & & & & & & & \\
\hline Quality & $-0.087^{*}$ & $0.108^{* *}$ & -0.056 & -0.011 & 1 & & & & & & & & \\
\hline VarEPS & -0.014 & $0.288^{* * *}$ & $-0.179 * * *$ & $-0.148^{* * *}$ & $0.199 * * *$ & 1 & & & & & & & \\
\hline DesvROA & $-0.097^{*}$ & 0.024 & $-0.322^{* * *}$ & $-0.240^{* * *}$ & $0.169^{* * *}$ & $0.345^{* * *}$ & 1 & & & & & & \\
\hline DivAnalysts & $0.130^{* *}$ & $0.345^{* * *}$ & $-0.239 * * *$ & $-0.214^{* * *}$ & $0.180^{* * *}$ & $0.235^{* * *}$ & 0.023 & 1 & & & & & \\
\hline IVRDI & $0.320^{* * *}$ & -0.033 & $0.160^{* * *}$ & $0.151^{* * *}$ & -0.059 & $-0.090^{*}$ & -0.005 & $0.102^{*}$ & 1 & & & & \\
\hline DVRDI & $0.939 * * *$ & 0.079 & $0.224^{* * *}$ & $0.096^{*}$ & -0.062 & 0.059 & -0.018 & $0.136 * *$ & $0.197^{* * *}$ & 1 & & & \\
\hline MVRDI & $0.687^{* * *}$ & 0.031 & $0.255^{* * *}$ & $0.199 * * *$ & $-0.095^{*}$ & $-0.142^{* * *}$ & $-0.230^{* * *}$ & 0.024 & $0.171^{* * *}$ & $0.424^{* * *}$ & 1 & & \\
\hline VRDI & $0.632^{* * *}$ & $0.128^{* *}$ & $0.230^{* * *}$ & $0.201 * * *$ & -0.070 & -0.010 & $-0.121 * *$ & $0.157^{* * *}$ & $0.386^{* * *}$ & $0.483^{* * *}$ & $0.629 * * *$ & 1 & \\
\hline NVRDI & $0.940^{* * *}$ & 0.028 & $0.235^{* * *}$ & $0.106^{* *}$ & -0.076 & -0.012 & -0.065 & $0.090^{*}$ & $0.220^{* * *}$ & $0.932^{* * *}$ & $0.561^{* * *}$ & $0.333^{* * *}$ & 1 \\
\hline
\end{tabular}

*** $p$-value $<0.01 ;{ }^{* *} p$-value $<0.05 ;{ }^{*} p$-value $<0.10$

Source: own elaboration.

Table 4. Estimation of the model 1

\begin{tabular}{lcc}
\hline Variable & Coefficient & p-value \\
\hline RDI & 0.000 & 0.558 \\
Big4 & 0.118 & 0.325 \\
Lev & -0.005 & $0.000^{* * *}$ \\
Size & 0.091 & $0.000^{* * *}$ \\
Analysts & -0.004 & 0.916 \\
Quality & -0.447 & $0.068^{*}$ \\
VarEPS & -0.211 & $0.000^{* * *}$ \\
DesvROA & 0.026 & $0.000^{* * *}$ \\
Loss & -0.153 & $0.000^{* * *}$ \\
DivAnalysts & -0.461 & $0.000^{* * *}$ \\
Multiple R-Squared & 0.714 & \\
Obs. & 351 & \\
Chi-sq (Haussman) test & 70.41 & $0.000^{* * *}$ \\
\hline
\end{tabular}

*** $p$-value $<0.01 ;{ }^{* *}$-value $<0.05 ;{ }^{*} p$-value $<0.10$

Source: own elaboration.

4.3. The effect of disclosing verifiable and verified risk information on the accuracy of analysts' earnings forecasts.

As in model 1, in models 2 and 3 we detected no residual autocorrelation (we performed the Durbin-Watson test) but we found heteroskedasticity problems (White's test) in the residuals of the models estimated through OLS. Therefore, we have also estimated these models using the Generalised Least Squares technique for panel data.

The model used to test the informative content of the three components (aspects) of the information in relation to their verifiability has been collected in equation (2).

The results of estimating this model (2) are shown in Table 5. As can be seen from the table, none of the coefficients for the factors into which the risk information disclosed by firms is broken down are statistically significant. That is, whether the information is verifiable or not does not influence forecast accuracy. For that reason, it cannot be concluded that verifiable information helps to reduce analysts' uncertainty in relation to the prediction of future cash flows to be generated by the firm. In this way, in relation to verifiable information, the second hypothesis is rejected.

As regards the control variables, both the sign and the statistical significance level are similar to those obtained with estimation of the model (1). Thus, the interpretation of the coefficients for the variables estimated with model (1) is directly transferable to those of model (2).

Finally, regarding the distinction between verified and non-verified risk information, Table 5 also reflects the result of the estimated model (3). According to this table, neither the variable corresponding to verified risk information (VRDI) nor the one corresponding to the non-verified risk information coefficient (NVRI) are statistically significant. With these results, hypothesis 2 must be rejected.

With respect to the control variables, identical considerations can be made as for model (2).

\section{Conclusions}

This paper has analysed the relationship between firm risk information disclosure and the accuracy of financial analysts' profit forecasts. Taking as the population non-financial firms listed on the Spanish Stock Exchange, for which this type of information (forecasts) is registered, two hypotheses have been tested: first, risk information, taken as a whole, is related to analysts' forecast accuracy. Second, verified or verifiable information is related to that accuracy.

With data from 2010 to 2015, after estimating three models, which include the control variables considered relevant in the literature, the conclusion is that the first hypothesis must be rejected. That is, greater forecast accuracy cannot be associated with greater disclosure of risk information. And as regards the second hypothesis, the part concerning verifiable information must also be rejected: no statistically significant relationship has been detected between the amount of verifiable risk information published, and analysts' forecast accuracy. The test with verified information provides the same result. 
Table 5. Estimation of models (2) and (3)

\begin{tabular}{|c|c|c|c|c|}
\hline \multirow[b]{2}{*}{ Variable } & \multicolumn{2}{|c|}{ Model (2) } & \multicolumn{2}{|c|}{ Model (3) } \\
\hline & Coefficient & p-value & Coefficient & $\mathrm{p}$-value \\
\hline IVRDI & -0.004 & 0.813 & & \\
\hline DVRDI & -0.000 & 0.829 & & \\
\hline MVRDI & 0.002 & 0.632 & & \\
\hline VRDI & & & -0.002 & 0.707 \\
\hline NVRDI & & & 0.001 & 0.492 \\
\hline Big4 & 0.118 & 0.326 & 0.108 & 0.376 \\
\hline Lev & -0.005 & $0.000^{* * *}$ & -0.005 & $0.009 * * *$ \\
\hline Size & 0.090 & $0.000 * * *$ & 0.093 & $0.000^{* * *}$ \\
\hline Analysts & -0.005 & 0.888 & -0.004 & 0.919 \\
\hline Quality & -0.447 & $0.063^{*}$ & -0.462 & $0.061^{*}$ \\
\hline VarEPS & -0.211 & $0.000^{* * *}$ & -0.209 & $0.000^{* * *}$ \\
\hline DesvROA & 0.026 & $0.000^{* * *}$ & 0.026 & $0.000^{* * *}$ \\
\hline Loss & -0.153 & $0.000^{* * *}$ & -0.151 & $0.000^{* * *}$ \\
\hline DivAnalysts & -0.460 & $0.000^{* * *}$ & -0.460 & $0.000^{* * *}$ \\
\hline $\begin{array}{l}\text { Multiple } \\
\text { R-Squared }\end{array}$ & 0.714 & & 0.716 & \\
\hline Obs. & 351 & & 351 & \\
\hline $\begin{array}{l}\text { Chi-sq } \\
\text { (Haussman) test }\end{array}$ & 71.501 & $0.000^{* * *}$ & 75.67 & $0.000^{* * *}$ \\
\hline
\end{tabular}

*** p-value $<0.01 ;{ }^{* *}$-value $<0.05 ;{ }^{*}$-value $<0.10$

Source: own elaboration.

In short, it cannot be concluded that the risk information firms disclose helps analysts to reduce their levels of uncertainty and thus make more accurate forecasts of future profits. Obviously, as in all empirical studies like this one, the results must be understood to be conditioned to the study population and time period.

\section{Conflict of interest}

The authors declare no conflict of interest.

\section{Annexes}

Table A1. Risk disclosure categories

\begin{tabular}{ll}
\hline 1 Financial risk & 2 Operations risk \\
Interest rate & Customer satisfaction \\
Exchange rate & Product development \\
Commodity & Efficiency and performance \\
Liquidity & Sourcing \\
Credit & Stock obsolescence and shrinkage \\
Other financial risks & Product and service failure \\
& Environmental Health and safety \\
& Brand name erosion \\
& Other operations risks \\
\hline Empowerment risk & $\begin{array}{l}\text { Information processing and technology } \\
\text { risk }\end{array}$ \\
Leadership and & Integrity \\
management & Access \\
Outsourcing & Availability \\
Performance incentives &
\end{tabular}

Table A1. Risk disclosure categories. (continuation)

\begin{tabular}{|c|c|}
\hline Change readiness & Infrastructure \\
\hline Communications & $\begin{array}{l}\text { Other Information processing and } \\
\text { technology risks }\end{array}$ \\
\hline \multicolumn{2}{|c|}{ Other empowerment risks } \\
\hline 5 Integrity risk & 6 Strategic risk \\
\hline $\begin{array}{l}\text { Management and } \\
\text { employee fraud }\end{array}$ & Environmental scan \\
\hline Illegal acts & Industry \\
\hline Reputation & Business portfolio \\
\hline \multirow[t]{9}{*}{ Other Integrity risks } & Competitors \\
\hline & Pricing \\
\hline & Valuation \\
\hline & Planning \\
\hline & Life cycle \\
\hline & Performance measurement \\
\hline & Regulatory \\
\hline & Sovereign and political \\
\hline & Other Strategic risks \\
\hline
\end{tabular}

Source: own elaboration.

\section{References}

Abarbanell, J. S., \& Lehavy, R. (2002). Differences in Commercial Database Reported Earnings: Implications for Empirical Research. Retrieved on May, 20, 2019, from: https://ssrn.com/abstract=228918 or http://dx.doi.org/10.2139/ssrn.228918

Abraham, S., Marston, C., \& Darby, P. (2012). Risk reporting: Clarity, relevance and location. Edinburgh: Institute of Chartered Accountants of Scotland.

Ahmed, A. S., Nainar, S. M. K., \& Zhou, J. (2005). Do analysts' earnings forecasts fully reflect the information in accruals? Canadian Journal of Administrative Sciences, 22(4), 329-342. https://doi.org/10.1111/j.1936-4490.2005.tb00378.x

Aljifri, K., \& Hussainey, K. (2007). The determinants of forward-looking information in annual reports of UAE companies. Managerial Auditing Journal, 22(9), 881-894. https://doi.org/10.1108/02686900710829390

American Institute of Certified Public Accountants. (1994). Improving Business Reporting: A Customer Focus. New York: AICPA.

American Institute of Certified Public Accountants. (1987). Report of the task force on risk and uncertainties. New York: AICPA.

Ashbaugh, H., \& Pincus, M. (2001). Domestic accounting standards, international accounting standards, and the predictability of earnings. Journal of Accounting Research, 39(3), 417-34. https://doi.org/10.1111/1475-679X.00020

Association of Chartered Certified Accountants. (2014). Risk reporting. London: ACCA.

Bamber, L. S., Barron, O. E., \& Stober, T. L. (1997). Trading volume and different aspects of disagreement coincident with earnings announcements. Accounting Review, 72(4), 575-597.

Barron, O. E., Kile, C. O., \& O'Keefe, T. B. (1999). MD\&A quality as measured by the SEC and analysts' earnings forecasts. Contemporary Accounting Research, 16(1), 75-109. https://doi.org/10.1111/j.1911-3846.1999.tb00575.x

Basu, S., Hwang, L., \& Jan, C. L. (1998). International variation in accounting measurement rules and analysts' earnings forecast errors. Journal of Business Finance \& Accounting, 25(9-10), 1207-1247. https://doi.org/10.1111/1468-5957.00234

Beattie, V., Mclnnes, B., \& Fearnley, S. (2004). A methodology for analysing and evaluating narratives in annual reports: a comprehensive descriptive profile and metrics for disclosure quality attributes. Accounting Forum, 28(3), 205-236. https://doi.org/10.1016/j.accfor.2004.07.001

Behn, B. K., Choi, J. H., \& Kang, T. (2008). Audit quality and properties of analyst earnings forecasts. The Accounting Review, 83(2), 327-349. https://doi.org/10.2308/accr.2008.83.2.327 
Beretta, S., \& Bozzolan, S. (2008). Quality versus quantity: the case of forward-looking disclosure. Journal of Accounting, Auditing \& Finance, 23(3), 333-376. https://doi.org/10.1177\%2F0148558X0802300304

Bernardi, C., \& Stark, A. W. (2018). Environmental, social and governance disclosure, integrated reporting, and the accuracy of analyst forecasts. The British Accounting Review, 50 (1), 16-31. https://doi.org/10.1016/j.bar.2016.10.001

Bozzolan, S., Trombetta, M., \& Beretta, S. (2009). Forward looking disclosures, financial verifiability and analysts' forecasts: a study of cross-listed European firms. European Accounting Review, 18(3), 435-473. https://doi.org/10.1080/09638180802627779

Brown, L. D. (1997). Analyst forecasting errors: Additional evidence. Financial Analysts Journal, 53(6), 81-88. https://doi.org/10.2469/faj.v53.n6.2133

Byard, D., Li, Y., \& Yu, Y., (2011). The effect of mandated IFRS adoption on analysts' forecast errors. Journal of Accounting Research, 49(1), 69-96. https://doi.org/10.1111/j.1475-679X.2010.00390.x

Cabedo, J. D., \& Tirado-Beltrán, J. M. (2014). Risk disclosure and cost of equity. The Spanish case. Contaduría y Administración, 59(4), 105-135. https://doi.org/10.1016/S0186-1042(14)70157-3

Cabedo, J. D., \& Tirado, J. M. (2004). The disclosure of risk in financial statements. Accounting Forum, 28(2), 181-200. https://doi.org/10.1016/j.accfor.2003.10.002

Cabedo, J. D., \& Tirado, J. M. (2009). Risk information disclosure: a proposal for measurement. Innovar, 19(34), 121-134.

Campbell, J. L., Chen, H., Dhaliwal, D. S., Lu, H. M., \& Steele, L. B. (2014). The information content of mandatory risk factor disclosures in corporate filings. Review of Accounting Studies, 19(1), 396-455. https://doi.org/10.1007/s11142-013-9258-3

Chang, M., Hooi, L., \& Wee, M. (2014). How does investor relations disclosure affect analysts' forecasts? Accounting \& Finance, 54(2), 365-391. https://doi.org/10.1111/acfi.12046

Crawford, V. P., \& Sobel, J. (1982). Strategic information transmission. Econometrica, 50(6), 1431-1451.

DeFond, M. L., \& Jiambalvo, J. (1994). Debt covenant violation and manipulation of accruals. Journal of Accounting and Economics, 17(1), 145-176. https://doi.org/10.1016/0165-4101(94)90008-6

Ding, F., Luo, W., Hao, X., \& Zhang, L. (2017). Does IFRS Adoption Increase the Accuracy of Chinese Analysts' Forecasts? Emerging Markets Finance and Trade, 53(5), 1107-1021. https://doi.org/10.1080/1540496X.2016.1276826

Dobler, M. (2008). Incentives for risk reporting-A discretionary disclosure and cheap talk approach. The International Journal of Accounting, 43(2), 184-206. https://doi.org/10.1016/j.intacc.2008.04.005

Duru, A., \& Reeb, D. M. (2002). International diversification and analysts' forecast accuracy and bias. The Accounting Review, 77(2), 415-433. https://doi.org/10.2308/accr.2002.77.2.415

Filzen, J. J. (2015). The information content of risk factor disclosures in quarterly reports. Accounting Horizons, 29(4), 887-916. https://doi.org/10.2308/acch-51175

Francis, J., \& Schipper, K. (1999). Have financial statements lost their relevance? Journal of Accounting Research, 37(2), 319-352.

Fried, D., \& Givoly, D. (1982). Financial analysts' forecasts of earnings: A better surrogate for market expectations. Journal of Accounting and Economics, 4(2), 85-107. https://doi.org/10.1016/0165-4101(82)90015-5

Garrido, P. \& Sanabria, S. (2014). The impact of mandatory IFRS adoption on financial analysts' earnings forecasts in Spain. Spanish Journal of Finance and Accounting, 43(2), 111-131. https://doi.org/10.1080/02102412.2014.911587

Glaum, M., Baetge, J., Grothe, A., \& Oberdörster, T. (2013). Introduction of international accounting standards, disclosure quality and accuracy of analysts' earnings forecasts. European Accounting Review, 22(1), 79-116. https://doi.org/10.1080/09638180.2011.558301

Gujarati, D.N. (2003). Basic Econometrics (4th ed.). Boston: McGraw-Hill.

Healy, P. M., \& Palepu, K. G. (2001). Information asymmetry, corporate disclosure, and the capital markets: A review of the empirical disclosure literature. Journal of Accounting and Economics, 31(1), 405-440. https://doi.org/10.1016/S0165-4101(01)00018-0

Healy, P. M., Hutton, A. P., \& Palepu, K. G. (1999). Stock performance and intermediation changes surrounding sustained increases in disclosure. Contemporary Accounting Research, 16(3), 485-520. https://doi.org/10.1111/j.1911-3846.1999.tb00592.x

Heinle, M., \& Smith, K. (2015). A theory of risk disclosure. Working paper, University of Pennsylvania.
Heinle, M. S., \& Smith, K. C. (2017). A theory of risk disclosure. Review of Accounting Studies, 22(4), 1459-1491. https://doi.org/10.1007/s11142-017-9414-2

Hodgdon, C., Tondkar, R., Harless, D., \& Adhikari, A. (2008). Compliance with IFRS disclosure requirements and individual analysts' forecast errors. Journal of International Accounting, Auditing and Taxation, 17(1), 1-13. https://doi.org/10.1016/j.intaccaudtax.2008.01.002

Hope, 0. K. (2003). Disclosure practices, enforcement of accounting standards, and analysts' forecast accuracy: An international study. Journal of Accounting Research, 41(2), 235-272. https://doi.org/10.1111/1475-679X.00102

Hope, O. K., Hu, D., \& Lu, H. (2016). The benefits of specific riskfactor disclosures. Review of Accounting Studies, 21(4), 1005-1045. https://doi.org/10.1007/s11142-016-9371-1

Horton, J., Serafeim, G. \& Serafeim, I. (2013). Does Mandatory IFRS Adoption Improve the Information Environment? Contemporary Accounting Research, 30(1), 388-423. https://doi.org/10.1111/j.1911-3846.2012.01159.x

Hutton, A. P., Lee, L. F., \& Shu, S. Z. (2012). Do managers always know better? The relative accuracy of management and analyst forecasts. Journal of Accounting Research, 50(5), 1217-1244. https://doi.org/10.1111/j.1475-679X.2012.00461.x

Hutton, A. P., Miller, G. S., \& Skinner, D. J. (2003). The role of supplementary statements with management earnings forecasts. Journal of Accounting Research, 41(5), 867-890. https://doi.org/10.1046/j.1475-679X.2003.00126.x

Institute of Chartered Accountants in England \& Wales. (1997). Financial Reporting of Risk: Proposals for a Statement of Business Risk. London: ICAEW.

Institute of Chartered Accountants in England \& Wales. (2011). Reporting Business Risks: Meeting Expectations. London: ICAEW.

International Financial Reporting Standard (IFRS No. 7). Financial Instruments: Disclosures. IASB.

Jaggi, J. \& Jain, R. (1998). An evaluation of financial analysts' earnings forecasts for Hong Kong firms. Journal of International Financial Management and Accounting, 9(3), 177-200. https://doi.org/10.1111/1467-646X.00036

Jones, J. J. (1991). Earnings management during import relief investigations. Journal of Accounting Research, 29(2), 193-228.

Jorgensen, B. N. \& Kirschenheiter, M. T. (2003). Discretionary risk disclosures. The Accounting Review, 78(2), 449-469. https://doi.org/10.2308/accr.2003.78.2.449

Jorion, P. (2002). How informative are value-at-risk disclosures? The Accounting Review, 77(4), 911-931. https://doi.org/10.2308/accr.2002.77.4.911

Kajüter, P. (2001). Risikoberichterstattung: Empirische Befunde und der Entwurf des DRS 5. Der Betrieb, 54(3), 105-111

Kou, W., \& Hussain, S. (2007). Predictive gains to segmental disclosure matrices, geographic information and industry sector comparability. The British Accounting Review, 39(3), 183-195. https://doi.org/10.1016/j.bar.2007.05.002

Kravet, T. \& Muslu, V. (2013). Textual risk disclosures and investors' risk perceptions. Review of Accounting Studies, 18(4), 1088-1122. https://doi.org/10.1007/s11142-013-9228-9

Kross, W., Ro, B., \& Schroeder, D. (1990). Earnings expectations: the analysts' information advantage. The Accounting Review, 65(2), 461-476.

Landis, J., \& Koch, G. (1977). The measurement of observer agreement for categorical data. Biometrics, 33(1), 159-74.

Lang, M. H., \& Lundholm, R. J. (1996). Corporate disclosure policy and analyst behavior. The Accounting Review, 71(4), 467-492.

Larrán M., \& Rees, W. P. (1999). Un análisis empírico de los pronósticos de los analistas financieros en el caso español. Revista española de financiación y contabilidad, 28(101), 675-730.

Lev, B., \& Zarowin, P. (1999). The boundaries of financial reporting and how to extend them, Journal of Accounting Research, 37(2), 353-385.

Ley Sociedades de Capital. (2010). Real Decreto Legislativo 1/2010, de 2 de julio, por el que se aprueba el texto refundido de la Ley de Sociedades de Capital.

Lin, B. X., \& Lin, C. M. (2017). SEC FRR No. 48 and analyst forecast accuracy. Applied Economics Letters, 24(6), 427-432. https://doi.org/10.1080/13504851.2016.1200174

Linsley, P. M., \& Shrives, P. J. (2006). Risk reporting: A study of risk disclosures in the annual reports of UK companies. The British Accounting Review, 38(4), 387-404. https://doi.org/10.1016/j.bar.2006.05.002

Linsmeier, T. J., Thornton, D. B., Venkatachalam, M., \& Welker, M. (2002). The effect of mandated market risk disclosures on trading volume sensitivity 
to interest rate, exchange rate, and commodity price movements. The Accounting Review, 77(2), 343-377.

https://doi.org/10.2308/accr.2002.77.2.343

Mercer, M. (2004). How do investors assess the credibility of management disclosures?. Accounting Horizons, 18(3), 185-196. https://doi.org/10.2308/acch.2004.18.3.185

Miihkinen, A. (2013). The usefulness of firm risk disclosures under different firm riskiness, investor-interest, and market conditions: New evidence from Finland. Advances in Accounting, 29(2), 312-331. https://doi.org/10.1016/j.adiac.2013.09.006

Moumen, N., Othman, H. B., \& Hussainey, K. (2015). The value relevance of risk disclosure in annual reports: Evidence from MENA emerging markets. Research in International Business and Finance, 34, 177-204. https://doi.org/10.1016/j.ribaf.2015.02.004

Nelson, M. W. \& Rupar, K. (2015). Numerical formats within risk disclosures and the moderating effect of investors' concerns about management discretion. The Accounting Review, 90(3), 1149-1168. https://doi.org/10.2308/accr-50916

Ng, J., Tuna, I., \& Verdi, R. (2013). Management forecast credibility and underreaction to news. Review of Accounting Studies, 18(4), 956-986. https://doi.org/10.1007/s11142-012-9217-4

Rajgopal, S. (1999). Early evidence on the informativeness of the SEC's market risk disclosures: The case of commodity price risk exposure of oil and gas producers. The Accounting Review, 74(3), 251-280. https://doi.org/10.2308/accr.1999.74.3.251

Ramnath, S., Rock, S., \& Shane, P. (2008). The financial analyst forecasting literature: A taxonomy with suggestions for further research. International Journal of Forecasting, 24(1), 34-75.

https://doi.org/10.1016/j.ijforecast.2007.12.006

Rogers, J. L., \& Stocken, P. C. (2005). Credibility of management forecasts. The Accounting Review, 80(4), 1233-1260. https://doi.org/10.2308/accr.2005.80.4.1233

Sarens, G., \& D'Onza, G. (2017). The perception of financial analysts on risk, risk management, and internal control disclosure: Evidence from Belgium and Italy. International Journal of Disclosure and Governance, 14(2), 118-138. https://doi.org/10.1057/s41310-016-0014-3

Solomon, J., Solomon, A., Norton, S. D., \& Joseph, N. L. (2000). A conceptual framework for corporate risk disclosure emerging from the agenda for corporate governance reform. The British Accounting Review, 32(4), 447478. https://doi.org/10.1006/bare.2000.0145

Tan, H., Wang, S., \& Welker, M. (2011). Analyst following and forecast accuracy after mandated IFRS adoptions. Journal of Accounting Research, 49(5), 1307-1357. https://doi.org/10.1111/j.1475-679X.2011.00422.x

Vanstraelen, A., Zarzeski, M. T., \& Robb, S. W. (2003). Corporate nonfinancial disclosure practices and financial analyst forecast ability across three European countries. Journal of International Financial Management \& Accounting, 14(3), 249-278. https://doi.org/10.1111/1467-646X.00098

Wu, Y., \& Wilson, M. (2016). Audit Quality and Analyst Forecast Accuracy: The Impact of Forecast Horizon and Other Modeling Choices. Auditing: A Journal of Practice \& Theory, 35(2), 167-185. https://doi.org/10.2308/ajpt-51216

Zreik, O., \& Louhichi, W. (2017). Risk sentiment and firms' liquidity in the French market. Research in International Business and Finance, 39(Part B), 809-823. https://doi.org/10.1016/j.ribaf.2014.11.003 